\title{
It's official! LASER THERAPY has been awarded PubMed Central listing!!
}

\author{
Toshio Ohshiro MD PhD
}

Welcome to the first issue of Volume 22 of the journal, and the very best of wishes from all at Laser Therapy for 2013, the Year of the Snake. The really good news to start off this Editorial is the fact that the PubMed Central (PMC) adjudication team has accepted Laser Therapy into the fold, and the journal will officially be indexed in PMC, the online database from the National Center for Biotechnology Information (NCBI) which is under the wing of the National Institutes of Health (NIH) of the USA. Together with our existing indexing which started one year ago in EmBase, the online version of the European Excerpta Medica, the availability of abstract, key word and author information from our articles to researchers, basing their literature searches on keywords, will ensure more and more citations of the journal. This will soon give Laser Therapy an impact factor (IF) value. At first it will be small, but I am confident we will see the IF gradually increase.

Towards that aim, I would like to make it clear that our criteria for publication will of necessity become even more strict to maintain and even raise the quality of the articles appearing in the journal, and that includes our commitment to publishing these articles in the correct style, aiming for a zero tolerance on typographical errors. I am sure some will sneak through .... the best of journals still has the odd typo. However, I am taking steps to make sure that these will be as few and far between as possible. I encourage you, our readers, to get writing, because now more than ever your article will make a difference to the available information on lasers and light sources in medicine and surgery, and you will become part of the vast PMC database with your name as valid search item.

\section{Cancellation of the Paris World Laser Congress, $20^{\text {th }}$ ISLSM and $3^{\text {rd }}$ WFSLMS Meeting}

Against that happy news just announced, we have a counterbalance of bad news. Professor Jean Abitbol, the President of the proposed World Laser Congress due to be held in Paris this coming June, was forced by circumstances beyond his control to cancel the meeting. Among the most important reasons cited were the very sad lack of response from commercial exhibitors despite interest having been expressed and promises made which would represent a potentially grave financial loss, and of course the current very unsettled international financial climate. This elicited a fairly panic-type reaction amongst ISLSM and WFSLMS Executive members with emails flying hither and yonder containing proposals and counter-proposals.

In his capacity as Secretary-General of the WFSLMS and Immediate Past President of the ISLSM, the author finally sent out to the ISLSM and WFSLMS Executive and Committee members a formal proposal for acknowledgement and approval, namely that the ISLSM/WFSLMS meeting should be held jointly in Vilnius, Lithuania, in September of this year, in cooperation with the $5^{\text {th }}$ congress of the International Phototherapy Association (IPTA) under the Meeting Presidency of Prof. Aurelija Vaitkuviene and with Prof. Juozas Vaitkus as the meeting Secretary-General. They had already very kindly agreed to the proposal in advance, should it be accepted. In fact the proposal was unanimously accepted, and so the $20^{\text {th }}$ ISLSM $/ 4^{\text {th }}$ WFSLMS meeting will take place together with the $5^{\text {th }}$ IPTA meeting from the $19^{\text {th }}$ to the $21^{\text {st }}$ of September, at the Radisson Blu Hotel Lietuva Congress Centre, Vilnius. The hotel is situated on the bank of the River Neris in the centre of Vilnius, only a 10-minute walk to the Medieval Old Town.

For full details of registration, abstract submission, accommodation and so on, please visit http://www.ipta2013.com/home. Thanks to the very willing cooperation of Profs Vaitkuviene and Vaitkus the author believes that victory may well have been snatched from the jaws of defeat. However, we are relying on you, faithful readers, members of the ISLSM, WFSLMS and of course IPTA to rally behind the orga- 
nizers. Following the enforced failure of his extremely ambitious plans for Paris, Prof Abitbol has elected to continue as the President of the ISLSM, so he urgently needs your support, as does the current WFSLMS President, Prof Krishna Rau and the President-Elect, Prof Leonardo Longo. Note the above dates in your diaries and online schedulers, visit the web site and LET'S GO TO VILNIUS in September!

\section{Annual Award: Best and Good Papers from Laser Therapy Volume 21}

It is with enormous pleasure that I can announce the winners of our annual Good/Best Papers award for Volume 21 of the journal. As always, the results were extremely tight and the members of the Editorial Board asked me to let you all know how difficult they found the decision, but it was finally made, and the results are as below:

\begin{tabular}{|l|l|}
\hline \multicolumn{2}{|l|}{ BEST PAPER (JPY 1,000,000) } \\
\hline Title: & Bone metabolism in cerebral palsy and the effect of light-emitting diode (LED) irradiation. \\
\hline Authors: & Yoshimi Asagai ${ }^{2}$, Kengo Yamamoto ${ }^{2}$, Toshio Ohshiro ${ }^{3}$, Takafumi Ohshiro ${ }^{4}$ \\
\hline Affiliations: & $\begin{array}{l}\text { 1) Shinano Handicapped Children's Hospital; 2) Department of Orthopedic Surgery, Tokyo } \\
\text { Medical University; 3) Japan Medical Laser Laboratory; 4) Ohshiro Clinic }\end{array}$ \\
\hline Published: & Laser Therapy, 2012; Vol. 21 No. 1: 23-31 \\
\hline GOOD PAPER AWARD (JPY 300,000) \\
\hline Title & $\begin{array}{l}\text { Reduction of monocyte chemoattractant protein-1 Expression in Pheumatoid arthritis rat joints } \\
\text { with Light-Emitting Diode phototherapy }\end{array}$ \\
\hline Authors & Noboru Kuboyama ${ }^{1}$ and Yoshimitsu Abiko 2 \\
\hline Affiliations & $\begin{array}{l}\text { 1) Department of Molecular Pharmacology, Nihon University School of Dentistry at Matsudo, } \\
\text { Chiba 271, Japan } \\
\text { 2) Department of Biochemistry and Molecular Biology, Nihon University School of Dentistry at } \\
\text { Matsudo, Chiba 271, Japan }\end{array}$ \\
\hline Published: & \begin{tabular}{l} 
Laser Therapy, Vol. 21 (2012) No. 3: 177-183. Issued as epub ahead of print \\
\hline GOOD PAPER AWARD (JPY 300,000)
\end{tabular} \\
\hline Title: & Laser acupuncture - innovative basic research: visual and laser-induced evoked potentials. \\
\hline Author: & Gerhard Litscher \\
\hline Published: & $\begin{array}{l}\text { Medical University of Graz, Stronach Research Unit for Complementary and Integrative Laser } \\
\text { Medicine; Research Unit of Biomedical Engineering in Anesthesia and Intensive Care Medicine; } \\
\text { and TCM Research Center Graz }\end{array}$ \\
\hline
\end{tabular}

Our sincere congratulations to the worthy winners, but my personal and sincere thanks to ALL who wrote and submitted articles for Volume 21. We are of course putting forward the same prize money for the Best Paper (JPY 1,000,000) and Good Papers awards (two at JPY 300,000 each) for this current Volume 22. To enter and have your article considered, all you have to do is submit a paper and get it accepted for publication .... it's as simple as that!

\section{Laser Therapy to become the official jour- nal for "Laser Florence"}

We are all well aware of Prof Leonardo Longo's very successful annual meeting, Laser Florence, which has been a bright light on the laser congress scene for some years. Prof Longo has approached the author as the Editor-in-Chief of Laser Therapy to suggest that the journal should become the official Laser Florence journal. The Editorial Board have considered the proposal, and have agreed that selected papers, appropriate for publication in the journal, will be published subject to the usual peer-review process. We are looking forward to starting a run of these selected articles from Laser Florence 2012 during this current volume, with the first one appearing in this issue. The high scientific quality of these papers will give you a very good idea of the high quality of Prof Longo's meeting. You can see his 
report on last year's meeting and a preliminary announcement for this year's meeting elsewhere in the journal.

\section{End Notes}

That brings us to the end of our first Editorial for Volume 22 of our PM-listed journal. As part of these end notes I would like to draw your attention to an article which appears in this issue of the journal, namely "Effect of Low-Level Laser Therapy on blood flow and oxygen-hemoglobin saturation of the foot skin in healthy subjects: a pilot study" by Franziska Heu, Clemens Forster, Barbara Namer, Adrian Dragu and Werner Lang with Dr Lang as the corresponding author. This paper shows negative results. A journal should never be constrained to publish only positive results, since a well-designed study which elicits negative results can be in its own way as valuable as one producing positive results. I have elected to publish this paper to show the necessity of having enough data on which to base results, positive or negative, and at the end of Heu and colleagues' paper I have appended a comment on the article, with the authors' permission. Please read the paper, and then the comment. Take this advice to heart when writing up a research study, indeed it should be part of the planning process even before the first experiment is done, to ensure that the data are adequate, have been appropriately elicited and deliver solid results from which it is possible to draw a definitive conclusion, be it positive or negative. 